\title{
Valon spektri säätelee ahomansikan (Fragaria vesca L.) rönsynmuodostusta ja kukintainduktiota
}

\author{
Marja Rantanen ${ }^{1)}$, Katriina Mouhu, Paula Elomaa, Timo Hytönen ja Pauliina Palonen \\ Soveltavan biologian laitos, Puutarhatiede, PL 27, 00014 Helsingin yliopisto \\ ${ }^{1)}$ marja.rantanen@helsinki.fi
}

\section{Tiivistelmä}

Valo on keskeinen kasvien kehitystä, kuten kukintaan virittymistä, ohjaava signaali. Valoreseptorien toimintaa ei tunneta geneettisellä tasolla tarkasti. Pitkänpäivänkasvi lituruoholla (Arabidopsis thaliana (L.) Heynh.) kukinta-aikaa säätelevät valon spektrin sininen, punainen ja kaukopunainen aallonpituusalue. Kaukopunainen ja sininen valo edistävät ja punainen valo estää kukintaa. Valodiodeilla (light emitting diodes, LED) valoa voidaan tuottaa hyvin kapealla aallonpituusalueella ja muuttaa valon laatua kasvin kasvun ja kehityksen ohjaamiseksi halutulla tavalla.

Ahomansikalla (Fragaria vesca L.) punaisen, kaukopunaisen ja sinisen valon vaikutuksia kukintaan ei ole tutkittu aikaisemmin. Ahomansikan kukinta indusoituu lyhyenpäivän olosuhteissa. Ahomansikalta tunnetaan kuitenkin myös päivänpituusmutantteja. Rönsytön lajike Baron Solemacher sekä rönsyjä muodostava lajike Hawaii-4 virittyvät kukintaan pitkänpäivän olosuhteissa. Tutkimuksen tavoitteena on selvittää valon laadun vaikutusta ahomansikan kukintaan käyttäen sinistä, punaista ja kaukopunaista valoa tuottavia LED-valaisimia sekä hehkulamppuvaloa päivänpidennysvalona.

Lajikkeella Hawaii-4 kaukopunainen ja hehkulampulla annettu päivänpidennys esti rönsyjen muodostusta ja edisti kukintainduktiota verrattuna punaiseen päivänpidennysvaloon ja lyhytpäiväkäsittelyyn. Myös kukinnan merkkigeeni FUL:n ilmenemistaso nousi kärkikasvupisteessä kukintaa edistäneissä käsittelyissä. Lajikkeella Baron Solemacher vain hehkulamppuvalo edisti kukintaa. Kaukopunainen, punainen ja lyhytpäiväkäsittely eivät eronneet toisistaan. Koe osoittaa fytokromisäätelyn keskeisen roolin kukintainduktiossa ja rönsynmuodostuksessa lajikkeella Hawaii-4.

Asiasanat: Fragaria, FUL, kukinta, LED (light emitting diode), mansikka, valon laatu 


\section{Johdanto}

Valo on kasveille energian lähde ja kehitystä ohjaava signaali esimerkiksi kukintainduktiossa. Kasvi aistii valon valoreseptorien kautta. Fytokromit (phyA-E) absorboivat kaukopunaista (FR) ja punaista (R) valoa ja kryptokromit (cry1, cry2) sinistä (B) valoa. Fotoreseptorit pystyvät erottamaan muutokset valon suunnassa, intensiteetissä ja spektrissä sekä valojakson pituudessa (Gyula ym. 2003).

Pitkänpäivänkasvi lituruoholla kukinta-aikaa säätelevät sininen, punainen ja kaukopunainen valon aallonpituusalue (Mockler ym. 2003). Kaukopunainen ja sininen valo edistävät ja punainen estää kukintaa (Lin 2000). Keskeiset kukintaa säätelevän valoreitin geenit ovat konservoituneet eri lajeilla (Hayama \& Coupland 2004), mutta lyhyenpäivän mallikasvi riisillä valoreitin geenit toimivat päinvastoin kuin pitkänpäivänkasvi lituruoholla (Cremer \& Coupland 2003; review Turck ym. 2008).

Ahomansikka virittyy kukintaan lyhyenpäivän olosuhteissa. Kukinta indusoituu $15-18{ }^{\circ} \mathrm{C}$ :ssa, kun päivänpituus alittaa 15 h (Heide \& Sønsteby 2007). Matalammassa lämpötilassa kukintainduktio tapahtuu kuitenkin päivänpituudesta riippumatta ja yli $21{ }^{\circ} \mathrm{C}$ :een lämpötila estää kukinnan virittymisen. Ahomansikalta tunnetaan myös päivänpituusmutantteja, kuten rönsytön lajike Baron Solemacher sekä rönsyjä muodostava lajike Hawaii-4. Ne virittyvät kukintaan pitkänpäivän olosuhteissa.

Ahomansikalla punaisen, kaukopunaisen ja sinisen valon vaikutuksia kukintaan ei ole tutkittu aikaisemmin. Valodiodeilla (light emitting diodes, LED) valoa voidaan tuottaa hyvin kapealla aallonpituusalueella, jolloin kasveille voidaan antaa haluttua valon aallonpituusaluetta. Tutkimuksemme tavoitteena on selvittää valon laadun vaikutusta ahomansikan kukinnan säätelyyn sekä LED-tekniikan käyttöä kasvin kasvun ja kehityksen ohjaamisessa.

\section{Aineisto ja menetelmät}

Kokeessa käytettiin ahomansikan pitkässä päivässä kukintaan indusoituvia genotyyppejä Baron Solemacher ja Hawaii-4. Siemenet kylvettiin suoraan $6 \times 6 \mathrm{~cm}$ ruukkuihin (Karkea ruukutusseos, Kekkilä Oyj, Tuusula, Suomi). Idätys tehtiin pitkässä päivässä. Siementaimet siirrettiin eri valokäsittelyihin sirkkalehti - 1lehtivaiheessa. Kasvuvalo (12 h) annettiin suurpainenatriumvalaisimilla (HPS). Valonlaatukäsittelyt tehtiin matalalla intensiteetillä $\left(8 \mu \mathrm{mol} \mathrm{m} \mathrm{m}^{-2} \mathrm{~s}^{-1}\right)$ päivänpidennyskäsittelyinä $(6 \mathrm{~h})$ LED-valaisimilla ja hehkulampulla. Valokäsittelyt olivat sininen (B) $(430 \mathrm{~nm})$, punainen $(\mathrm{R})(660 \mathrm{~nm})$ ja kaukopunainen $(F R)(735 \mathrm{~nm})$ sekä hehkulamppuvalo (INC). Kontrollikäsittelylle (SD) ei annettu päivänpidennysvaloa. Kasvien lehtien kehitystä havainnoitiin ja viikoittain kerättiin kasvupistenäytteet geeniekspressioanalyysiä varten. Kolmen tai viiden viikon käsittelyjaksojen jälkeen kasvit siirrettiin pitkän päivän (18 h, HPS) olosuhteisiin kukintahyötöä varten. Kukinnan alkaminen määritettiin kehitysvaiheeseen perustuen laskemalla, miten monta lehteä kasvissa oli ennen kukintoa.

\section{Geeniekspressioanalyysi}

Kokeesta kerättiin versonkärkinäytteet viikoittain valokäsittelyiden ajan. Versonkärkinäytteisiin leikattiin kymmenen kasvin versonkärki noin $1 \mathrm{~mm}: n$ pituudelta. Näytteet jäädytettiin välittömästi nestetypessä ja säilytettiin analyysiä varten $-70^{\circ} \mathrm{C}$ :ssa.

Kukinnan merkkigeenin FUL (Mouhu ym. 2009) ilmenemistaso määritettiin käyttäen kvantitatiivista real time -PCR menetelmää. Näytteet jauhettiin hienoksi jauheeksi nestetypessä ja niistä eristettiin kokonaisRNA käyttäen männylle kehitettyä menetelmää (Monte \& Somerville 2002). RNA:sta syntetisoitiin cDNA Superscript III RT kittiä (Invitrogen, Carlsbad, Yhdysvallat) ja ankkurialukkeita käyttäen. Kvantitatiivinen RT-PCR tehtiin 384 kaivon levyllä Light Cycler 480 -laitteella (Roche diagnostics, Indianapolis, Yhdysvallat). $F U L$-geenin ilmeneminen normalisoitiin $M S I$ - ja $F V E$ - geeneihin, jotka ilmenevät stabiilisti.

\section{Tulokset ja tulosten tarkastelu}

Päivänpidennys punaisella tai hehkulamppuvalolla takasi kasvien hyvän kasvun. Kaukopunainen päivänpidennysvalo aiheutti kuitenkin varjonvälttelyvaikutuksen ja kasvien lehtiruodit pidentyivät muutaman päivän jälkeen käsittelyn aloittamisesta. Lehdet olivat myös hyvin vaalean vihreitä ja kasvit kasvoivat heikosti.

Rönsyjen muodostus alkoi genotyypillä Hawaii-4 noin kolme viikkoa käsittelyiden aloittamisesta. Rönsyjä muodostui voimakkaasti punaisessa päivänpidennyskäsittelyssä, jossa kasvit käyttäytyivät samoin kuin lyhyenpäivän olosuhteissa (Taulukko 1). Kaukopunainen päivänpidennyskäsittely esti rönsyjen muodostusta samoin kuin hehkulamppukäsittely. 
Rönsynmuodostusta hidastaneet valokäsittelyt, kaukopunainen ja hehkulamppuvalo, edistivät kukintaa (Taulukko 1). Näissä käsittelyissä Hawaii-4 muodosti noin neljä lehteä vähemmän ennen kukintoa punaiseen valoon ja lyhytpäiväkäsittelyyn verrattuna. Punaisessa valossa ja lyhyessä päivässä kukintainduktio tapahtui todennäköisesti vasta, kun kasvit oli siirretty käsittelyistä pitkän päivän olosuhteisiin. Tulokset tukevat aikaisempia havaintoja, että kukinta ja rönsynmuodostus ovat antagonistisia kehitystapahtumia Hawaii-4 genotyypillä (Hytönen 2009).

Genotyyppien välillä näytti kuitenkin olevan eroa valon laatuun reagoimisessa. Rönsyttömällä Baron Solemacher -genotyypillä punainen valo viivästytti kukintaa samoin kuin lyhytpäiväkäsittely ja hehkulamppuvalossa kasvit kukkivat aikaisin. Myös kaukopunainen käsittely näytti edistävän joidenkin kasvien kukintaa, mutta jotkut kasvit kukkivat erittäin myöhään. Suuri hajonta kukinta-ajassa aiheutui todennäköisesti kasvien heikosta kasvusta kaukopunaisen valon käsittelyssä. Vaikka kukintainduktio olisikin tapahtunut, kukka-aiheiden kehittymisen esti resurssien vähyys.

Geeniekspressioanalyysissä tutkittiin kukinnan merkkigeenin, FUL (Mouhu ym 2009), ilmenemistä eri kehitysvaiheissa. FUL -geenin ilmenemistaso Hawaii-4:n kasvupisteissä korreloi fenologisten havaintojen kanssa. Sekä kaukopunainen että hehkulamppuvalo aktivoivat $F U L$-geenin ilmenemisen, mutta punaisessa valossa ja lyhyenpäivän käsittelyssä $F U L$-geenin ilmenemistaso säilyi alhaisella tasolla. Tulokset osoittavat, että punaisen ja kaukopunaisen valon reseptori fytokromi säätelee kukintaa ja rönsynmuodostusta ahomansikan pitkänpäivän genotyypeillä.

Taulukko 1. Rönsyjen muodostus, lehtien lukumäärä ennen kukintoa ja kukintamerkkigeenin $F U L$ ilmenemistaso eri valokäsittelyiden jälkeen. $\mathrm{SD}=$ lyhyt päivä, $\mathrm{R}=$ punainen päivänpidennys $(660 \mathrm{~nm}) 6 \mathrm{~h}, \mathrm{FR}=\mathrm{kaukopunainen}$ päivänpidennys $(735 \mathrm{~nm}) 6 \mathrm{~h}, \mathrm{INC}=$ hehkulamppupäivänpidennys $6 \mathrm{~h}$. Merkitsevät erot on osoitettu kirjaimilla riveittäin (Tukey:n testi, $\mathrm{p}<0,05$ ).

Käsittely P-arvo ANOVA

\begin{tabular}{lllllll} 
& Genotyyppi & SD & SD+ R & SD+ FR & SD+ INC & \\
\cline { 3 - 5 } & Hawaii-4 & $6 \mathrm{a}$ & $6,8 \mathrm{a}$ & $1,7 \mathrm{~b}$ & $1 \mathrm{~b}$ & $<0,001$ \\
\hline $\begin{array}{l}\text { Rönsyjen lukumäärä 5 viikon } \\
\text { käsittelyn jälkeen }\end{array}$ & Baron Solemacher & $11 \mathrm{a}$ & $9,6 \mathrm{a}$ & $8,5 \mathrm{a}$ & $6,6 \mathrm{~b}$ & $<0,001$ \\
$\begin{array}{l}\text { Lehtien lukumäärä ennen } \\
\text { kukintoa }\end{array}$ & Hawaii-4 & $12 \mathrm{a}$ & $12 \mathrm{a}$ & $8,4 \mathrm{~b}$ & $8,1 \mathrm{~b}$ & $<0,001$ \\
& Hawaii-4 & 0,64 & 0,65 & 5,29 & 11,79 & y \\
$\begin{array}{l}\text { FUL-geenin suhteellinen } \\
\text { ilmenemistaso kasvupisteessä } \\
\text { (normalisointigeeni=1) }\end{array}$ & & & & & &
\end{tabular}

${ }^{\mathrm{y}}$ Arvot ovat kahden biologisen toiston keskiarvoja.

\section{Johtopäätökset}

Kokeemme osoitti, että kukinnan säätely ahomansikalla on fytokromisäätelyn alaista. Päivänpidennys kaukopunaisella tai hehkulamppuvalolla edistää kukintaa ja estää rönsynmuodostusta ahomansikan pitkänpäivän genotyypeillä. Kukintainduktion merkkigeenin $F U L$ ilmenemistaso on linjassa fenotyyppisten havaintojen kanssa.

\section{Kirjallisuus}

Corbesier, L., Vincent, C., Jang, S., Fornara, F., Fan, Q., Searle, I., Giakountis, A., Farrona, S., Gissot, L., Turnbull, C. \& Coupland, G. 2007. FT protein movement contributes to long-distance signaling in floral induction of Arabidopsis. Science 316: 1030-1033.

Cremer \& Coupland. 2003. Distinct photoperiodic responses are conferred by the same genetic pathway in Arabidopsis and in rice. Trends in Plant Science 8: 405-407.

Gyula et al. 2003. Light perception and signalling in higher plants. Curr. Opinion Plant Biol. 6: 446-452. 
Hayama \& Coupland, G. 2004. The molecular basis of diversity in the photoperiodic flowering responses of Arabidopsis and rice. Plant Phys. 135:677-684.

Heide, O. \& Sønsteby, A. 2007. Interactions of temperature and photoperiod in the control of flowering of latitudinal and altitudinal populations of wild strawberry (Fragaria vesca). Physiologia plantarum 130: 280-289.

Hytönen, T. 2009. Regulation of strawberry growth and development. Väitöskirja, Soveltavan biologian laitos, Helsingin yliopisto.

Lin, C. 2000. Photoreceptors and regulation of flowering time. Plant Phys. 123: 39-50.

Mockler, T., Yang, H., Yu, X., Parikh, D., Cheng, Y., Dolan, S. \& Lin, C. 2003. Regulation of photoperiodic flowering by Arabidopsis photoreceptors. PNAS 100: 2140-2145.

Monte, D. \& Somerville, S. 2002. Pine tree method for isolation of plant RNA. Teoksessa: Bowtel, D. \& Sambrook, J. (toim.). DNA microarrays: a molecular cloning manual. New York. Cold Spring Harbour Laboratory Press. s. 124-126.

Mouhu, K., Hytönen, T., Folta, K., Rantanen, M., Auvinen, P., Paulin, L. \& Elomaa, P. 2009. Identification of flowering genes in strawberry, a perennial SD plant. BMC Plant Biology 9:122.

Turck, F., Fornara, F. \& Coupland, G. 2008. Regulation and identity of florigen: FLOWERING LOCUS T moves center stage. Annu. Rev. Plant Biol. 59: 573-579.

Valverde, F., Mouradov, A., Soppe, W., Ravenscroft, D., Samach, A. \& Coupland, G. 2004. Photoreceptor regulation of CONSTANS protein in photoperiodic flowering. Science 303: 1003-1006. 